\title{
A budget impact analysis of substituting sitagliptin with liraglutide in type 2 diabetes from a private health insurance perspective in Egypt
}

Gihan Hamdy Elsisi ${ }^{1,2^{*} \mathbb{C}}$, Ayman Afify ${ }^{3}$, Ashraf Abgad ${ }^{4}$, Ibtissam Zakaria ${ }^{5}$, Nabil Nasif ${ }^{6}$, Hani Naiem Ibrahim , Nabil Raafat ${ }^{8}$ and João L. Carapinha ${ }^{9}$

\begin{abstract}
Introduction: Type 2 diabetes mellitus causes a sizable burden globally from both health and economic points of view. This study aimed to assess the budget impact of substituting sitagliptin with liraglutide versus other glucoselowering drugs from the private health insurance perspective in Egypt over a 3-year time horizon.
\end{abstract}

Methods: Two budget impact models were compared with the standard of care (metformin, pioglitazone, gliclazide, insulin glargine, repaglinide, and empagliflozin) administered in addition to liraglutide or sitagliptin versus the standard of care with placebo. A gradual market introduction of liraglutide or sitagliptin was assumed, and the existing market shares for the other glucose-lowering drugs were provided and validated by the Expert Panel. The event rates were extracted from the LEADER and TECOS trials. Direct and mortality costs were measured. Sensitivity analyses were performed.

Results: The estimated target population of 120,574 type 2 diabetic adult patients was associated with cardio vascular risk. The budget impact per patient per month for liraglutide is EGP29 (\$6.7), EGP39 (\$9), and EGP49 (\$11.3) in the 1st, 2nd, and 3rd years, respectively. The budget impact per patient per month for sitagliptin is EGP11 (\$2.5), EGP14 (\$3.2), and EGP18 (\$4.1) in the 1st, 2nd, and 3rd years, respectively. Furthermore, adoption of liraglutide resulted in 203 fewer deaths and 550 avoided hospitalizations, while sitagliptin resulted in 43 increased deaths and 14 avoided hospitalizations. The treatment costs of liraglutide use are mostly offset by substantial savings due to fewer cardiovascularrelated events, avoided mortality and avoided hospitalizations over 3 years.

Conclusion: Adding liraglutide resulted in a modest budget impact, suggesting that the upfront drug costs were offset by budget savings due to fewer cardiovascular-related complications and deaths avoided compared to the standard of care. Sitagliptin resulted in a small budget impact but was associated with increased deaths and fewer hospitalizations avoided.

*Correspondence: Gihanhamdyelsisi@hotmail.com

${ }^{1}$ HTA Office, LLC, Cairo, Egypt

Full list of author information is available at the end of the article

\section{Key points}

The upfront drug costs of adding liraglutide were offset by budget savings due to fewer CV-related complications and deaths avoided compared to the standard of care (modest budget impact). Sitagliptin resulted in a small budget impact but was associated with increased deaths

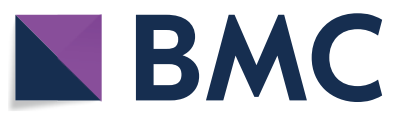

(c) The Author(s) 2022. Open Access This article is licensed under a Creative Commons Attribution 4.0 International License, which permits use, sharing, adaptation, distribution and reproduction in any medium or format, as long as you give appropriate credit to the original author(s) and the source, provide a link to the Creative Commons licence, and indicate if changes were made. The images or other third party material in this article are included in the article's Creative Commons licence, unless indicated otherwise in a credit line to the material. If material is not included in the article's Creative Commons licence and your intended use is not permitted by statutory regulation or exceeds the permitted use, you will need to obtain permission directly from the copyright holder. To view a copy of this licence, visit http://creativecommons.org/licenses/by/4.0/. The Creative Commons Public Domain Dedication waiver (http://creativecommons.org/publicdomain/zero/1.0/) applies to the data made available in this article, unless otherwise stated in a credit line to the data. 
and fewer hospitalizations avoided. This study will help to guide reimbursement decisions in Egypt.

\section{Introduction}

Diabetes mellitus is a chronic disease characterized by high levels of plasma glucose and deficiency in insulin production or utilization. Diabetes causes a sizable burden globally from both health and economic points of view. In 2017, the International Diabetes Federation (IDF) estimated that the number of people suffering from diabetes worldwide was 425 million, a number that is expected to increase to 629 million by 2045 [1]. Of the current diabetic population, $79 \%$ are from low- and middle-income countries, and the highest prevalence is among people aged 40 and 59 [1]. Diabetes costs public health systems around the world approximately 727 billion USD and caused 4 million deaths in 2017 [1].

The IDF ranked Egypt as the ninth highest country in the number of type 2 diabetes mellitus (T2DM) patients [2]. The number of T2DM patients has increased threefold over 20 years ago, with a current prevalence of $15.6 \%$ among the 20 to 79 age group [2]. T2DM is a metabolic disease associated with microvascular and macrovascular complications. Optimal glucose control is associated with a reduced risk of microvascular complications (retinopathy, nephropathy, and neuropathy) and benefits for macrovascular complications (reduced rates of heart attacks, strokes and improved blood flow to legs) [3].

Liraglutide is a subcutaneous injection (approved in Egypt for treating T2DM), a human glucagon-like peptide 1 (GLP-1) with an established plasma glucoselowering effect, thus reducing the risk of microvascular complications [3]. The effects of glycemic control on macrovascular complications were evaluated in the LEADER clinical trial [3]. The primary outcome in this trial (first occurrence of death from CV causes, nonfatal myocardial infarction, or nonfatal stroke) occurred in the liraglutide group [13.0\%] was fewer than in the placebo group [14.9\%] (hazard ratio, 0.87 ; 95\% confidence interval [CI] 0.78 to $0.97 ; \mathrm{P}<0.001$ for noninferiority; $\mathrm{P}=0.01$ for superiority) [3]. Sitagliptin, an orally administered dipeptidyl peptidase 4 (DPP-4) inhibitor, had been registered in Egypt [4]. Sitagliptin prolongs the action of incretin hormones, by inhibiting the breakdown of GLP-1 and glucose-dependent insulinotropic polypeptide [4]. The primary composite outcome for TECOS trial, a noninferiority trial, was $\mathrm{CV}$ death, nonfatal stroke, nonfatal $\mathrm{MI}$ and hospitalization for unstable angina [4]. Sitagliptin (11.4\%) was noninferior to placebo (11.6\%) for the primary outcome (hazard ratio, 0.98 ; $95 \%$ CI 0.88 to 1.09 ; $\mathrm{P}<0.001)$ [4].

The Egyptian health care system is fragmented and has different payers and providers. The private health insurance system is a key payer among multiple payers in Egypt. In order to provide the private health insurers with evidence to build their decisions on, and giving that efficient spending in healthcare is well known to be a direct predictor of better health outcomes and national wealth, we conducted our study to evaluate the budget impact of substituting sitagliptin with liraglutide versus other glucose-lowering drugs (metformin, pioglitazone, gliclazide, insulin glargine, repaglinide, and empagliflozin) from the private health insurance perspective in Egypt over a 3-year time horizon.

\section{Methodology \\ Population and treatment mix}

Two budget impact models were constructed. The first model assessed the budget impact of liraglutide plus the existing therapy (glucose-lowering drugs; metformin, pioglitazone, gliclazide, insulin glargine, repaglinide, and empagliflozin) versus the existing therapy alone, while the second model assessed the budget impact of the use of sitagliptin plus the existing therapy (mentioned above) versus the existing therapy alone. The target population of T2DM patients was estimated with the current Egyptian adult population and the prevalence of T2DM in Egypt $[2,5]$. The estimated target population was then narrowed to a group of diagnosed and treated patients at risk of cardiovascular events, as demonstrated in Fig. 1 [6]. This study focused exclusively on the proportion of this patient group covered by private health insurance companies [7]. The number of targeted patients was estimated to be 120,574 . A gradual market introduction of liraglutide or sitagliptin was assumed, and the existing market shares for the other glucose-lowering drugs were provided and validated by the Expert Panel.

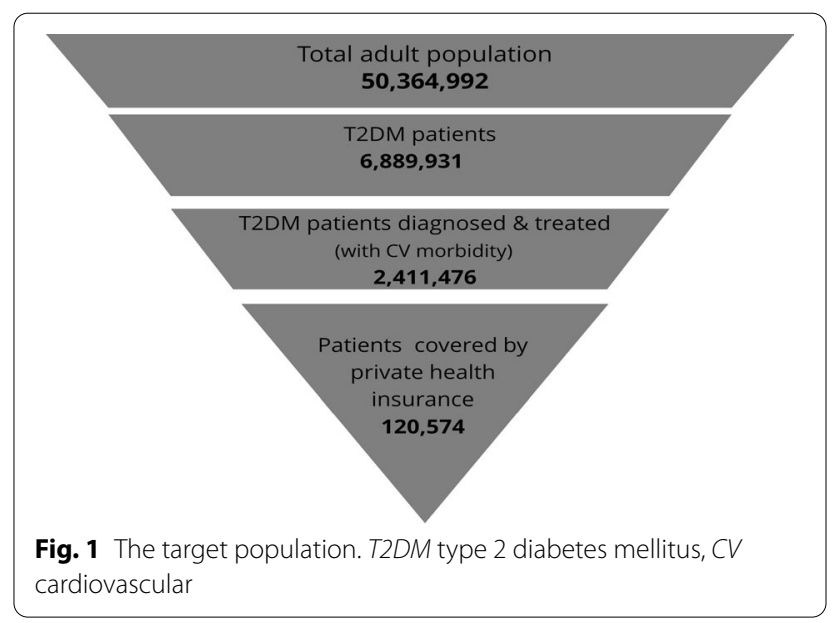




\section{Clinical parameters}

The event rates for cardiovascular complications were extracted from the LEADER trial [3]. This trial was a double-blind randomized trial included 9340 participants at randomization to investigate the cardiovascular safety of liraglutide versus the standard of care (metformin, thiazolidinedione, sulfonylureas, insulin, meglitinides and FGABG (SGLT2i)) in T2DM patients with a high risk for cardiovascular (CV) events [3]. The events considered in this study included mortality, myocardial infarction, stroke, heart failure (HF), coronary revascularization, and microvascular complications (retinopathy and nephropathy). The event rate difference per complication (liraglutide vs. standard of care) was multiplied by the number of patients on liraglutide to determine the number of cardiovascular events avoided. Similarly, sitagliptin inputs were extracted from the TECOS trial, a randomized, double-blind study that assigned 14,671 patients to add either sitagliptin or placebo to their existing therapy [4]. The median follow-up was 3 years to assess the cardiovascular implications of adding sitagliptin to the standard of care for T2DM patients. The clinical parameters extracted from the two studies were different but we did not standardize these parameters because we were measuring all the direct medical costs in the real-world practice. All clinical parameters were included in the model (Table 1).

\section{Costs}

Direct medical costs were estimated for drug acquisition, drug administration, complication management, followup and adverse event costs. All unit costs of medications were extracted from the private health insurance payer lists as fixed reimbursement amounts and multiplied by the drug utilization to obtain monthly and annual costs for liraglutide, sitagliptin, metformin, thiazolidinediones, sulfonylureas, insulin, meglitinides and SGLT2i. The drug utilization proportions were extracted from the LEADER and TECOS trials $[3,4]$.

The average management cost for $\mathrm{MI}$ and unstable angina included the cost of diagnostic tests (CT scan and ECG test), either percutaneous coronary intervention (PCI) or coronary artery bypass graft (CABG) intervention, and a 7-day hospital stay including appropriate treatment. The management cost for stroke included brain magnetic resonance imaging (MRI), 6 days in the ICU and 6 days in the general ward, including appropriate treatment. The heart failure management costs were composed of diagnostic tests (echo Doppler and ECG tests), 4 days in the ICU and 10 days in general ward costs including appropriate treatment. The costs of retinopathy included corrective surgery and measures for better glycemic control, and the costs of nephropathy included measures to control blood pressure, hemodialysis to counteract kidney damage, and glomerular filtration rate (GFR) tests every 3 months.

The drug-related adverse events included were acute pancreatitis, pancreatic cancer, and severe hypoglycemia [3, 4]. Pancreatitis management costs comprised the cost of 7 days in the intensive care unit (ICU), 3 days of hospitalization in a ward, pain killers and antibiotics. For the average management cost of pancreatic cancer, it was assumed to be limited to the annual price of erlotinib, an epidermal growth factor receptor (EGFR) tyrosine kinase inhibitor approved for the management of pancreatic cancer, which is given daily via the oral route. The cost of severe hypoglycaemia management was calculated as the summation of 4 days of hospitalization, admission to the emergency room, glucose intravenous administration, and laboratory tests (creatinine test, GFR tests, liver function tests, and glucose tests). All unit costs were extracted from private insurance hospitals [8].

Mortality costs were also considered in our analysis. Even though indirect costs are not typically included in budget impact analysis, according to the ISPOR task force for good research practices for budget impact analysis, we considered mortality, as private insurance companies have to pay compensation to the patients' family in case of death based on contracted life insurance policies [9]. To measure the cost of mortality, each patient's life was estimated to have the stated value mentioned in the life insurance policy agreements.

The total event cost for each complication was multiplied by the event rate in each treatment arm (from the LEADER and TECOS trials) to determine the total cost per event. The medication costs were included with event costs, and the total cost difference of liraglutide vs without liraglutide was calculated as the budget impact of adopting liraglutide in T2DM patients with cardiovascular risks from the private health insurance perspective in Egypt. Similarly, the budget impact of sitagliptin vs without sitagliptin was calculated in T2DM patients with cardiovascular risks from the private health insurance perspective. Both liraglutide and sitagliptin were compared to placebo/standard of care. No direct comparison was made between the two interventions. All unit costs in this study were calculated in Egyptian Pounds (EGP) set in 2020 and were exchanged to USD using the purchasing power parity rate. The time horizon for the study was 3 years.

\section{Sensitivity analyses}

To investigate the robustness of our study, one-way sensitivity analyses were conducted. All hazard ratios for the $\mathrm{CV}$ and non-CV outcomes were varied across its 
Table 1 The model inputs parameters

\begin{tabular}{|c|c|c|c|c|}
\hline Parameter & Mean value & Low value & High value & Sources \\
\hline \multicolumn{5}{|l|}{ Population data } \\
\hline Total adult population & $50,364,992$ & $40,291,994$ & $60,437,990$ & [5] \\
\hline T2DM prevalence & $13.7 \%$ & $10.9 \%$ & $16.4 \%$ & [2] \\
\hline $\begin{array}{l}\text { Proportion of patients with Type } 2 \text { Diabetes diagnosed and treated (with CV } \\
\text { morbidity) }\end{array}$ & $35 \%$ & $28 \%$ & $42 \%$ & [6] \\
\hline Proportion of patients covered by private insurance companies in Egypt & $5 \%$ & $4 \%$ & $6 \%$ & [7] \\
\hline GLP-1RA adoption year 1 & $3 \%$ & $2.4 \%$ & $3.6 \%$ & IMS data \\
\hline GLP-1RA adoption year 2 & $4 \%$ & $3.2 \%$ & $4.8 \%$ & IMS data \\
\hline GLP-1RA adoption year 3 & $5 \%$ & $4 \%$ & $6 \%$ & IMS data \\
\hline \multicolumn{5}{|l|}{ Clinical parameters from the LEADER trial } \\
\hline $\mathrm{Ml}^{\mathrm{a}}$ & $-0.80 \%$ & -0.00640 & -0.00960 & [3] \\
\hline Ischemic stroke ${ }^{a}$ & $-0.40 \%$ & -0.00320 & -0.00480 & [3] \\
\hline HF (hospitalization) ${ }^{\mathrm{a}}$ & $-0.60 \%$ & -0.00480 & -0.00720 & [3] \\
\hline Coronary revascularization $^{\mathrm{a}}$ & $-0.70 \%$ & -0.00560 & -0.00840 & [3] \\
\hline Retinopathy ${ }^{a}$ & $0.30 \%$ & 0.00240 & 0.00360 & [3] \\
\hline Nephropathy ${ }^{a}$ & $-1.50 \%$ & -0.01200 & -0.01800 & [3] \\
\hline Unstable angina pectoris (hospitalization) ${ }^{a}$ & $-0.10 \%$ & -0.00080 & -0.00120 & [3] \\
\hline All-cause mortality ${ }^{\mathrm{a}}$ & $-1.40 \%$ & -0.01120 & -0.01680 & [3] \\
\hline \multicolumn{5}{|l|}{ Clinical parameters from the TECOS trial } \\
\hline$M \mathrm{I}^{\mathrm{b}}$ & $-0.10 \%$ & -0.00080 & -0.00120 & [4] \\
\hline Ischemic stroke $e^{b}$ & $-0.20 \%$ & -0.00160 & -0.00240 & [4] \\
\hline Unstable angina pectoris (hospitalization) ${ }^{b}$ & $-0.20 \%$ & -0.00160 & -0.00240 & [4] \\
\hline Severe hypoglycemia ${ }^{\mathrm{b}}$ & $0.30 \%$ & 0.00240 & 0.00360 & [4] \\
\hline CV death ${ }^{b}$ & $0.30 \%$ & 0.00240 & 0.00360 & [4] \\
\hline Acute pancreatitis ${ }^{b}$ & $0.10 \%$ & 0.00080 & 0.00120 & [4] \\
\hline HF (hospitalization) $)^{b}$ & $0.10 \%$ & 0.00080 & 0.00120 & [4] \\
\hline Pancreatic cancer ${ }^{\mathrm{b}}$ & $-0.10 \%$ & -0.00080 & -0.00120 & [4] \\
\hline \multicolumn{5}{|l|}{ Treatment costs per unit (Egyptian Pounds) } \\
\hline Liraglutide & $\begin{array}{l}87.60 \\
20.37 \text { USD }\end{array}$ & $\begin{array}{l}70.08 \\
16.29 \text { USD }\end{array}$ & $\begin{array}{l}105.12 \\
24.44 \text { USD }\end{array}$ & [8] \\
\hline Sitagliptin 100 & $\begin{array}{l}11.00 \\
2.55 \text { USD }\end{array}$ & $\begin{array}{l}8.80 \\
2.04 \text { USD }\end{array}$ & $\begin{array}{l}13.20 \\
3.06 \text { USD }\end{array}$ & [8] \\
\hline Metformin 1000 & $\begin{array}{l}0.90 \\
0.209 \text { USD }\end{array}$ & $\begin{array}{l}0.72 \\
0.16 \text { USD }\end{array}$ & $\begin{array}{l}1.08 \\
0.25 \text { USD }\end{array}$ & [8] \\
\hline Insulin (glargine) $100 \mathrm{IU}$ & $\begin{array}{l}126.00 \\
29.30 \text { USD }\end{array}$ & $\begin{array}{l}100.80 \\
23.44 \text { USD }\end{array}$ & $\begin{array}{l}151.20 \\
35.16 \text { USD }\end{array}$ & {$[8]$} \\
\hline SU (gliclazide 60 mg) & $\begin{array}{l}1.58 \\
0.36 \text { USD }\end{array}$ & $\begin{array}{l}1.26 \\
0.29 \text { USD }\end{array}$ & $\begin{array}{l}1.89 \\
0.43 \text { USD }\end{array}$ & [8] \\
\hline TZD (pioglitazone 15 mg) & $\begin{array}{l}5.13 \\
1.19 \text { USD }\end{array}$ & $\begin{array}{l}4.11 \\
0.95 \text { USD }\end{array}$ & $\begin{array}{l}6.16 \\
1.43 \text { USD }\end{array}$ & {$[8]$} \\
\hline Novonorm 2 mg (repaglinide) & $\begin{array}{l}1.47 \\
0.34 \text { USD }\end{array}$ & $\begin{array}{l}1.17 \\
0.27 \text { USD }\end{array}$ & $\begin{array}{l}1.76 \\
0.40 \text { USD }\end{array}$ & {$[8]$} \\
\hline SGLT2i (empagliflozin) & $\begin{array}{l}16.53 \\
3.84 \text { USD }\end{array}$ & $\begin{array}{l}13.23 \\
3.07 \text { USD }\end{array}$ & $\begin{array}{l}19.84 \\
4.61 \text { USD }\end{array}$ & [8] \\
\hline \multicolumn{5}{|l|}{ Event costs excluding medicines (in Egyptian Pounds) } \\
\hline Non-fatal Ml & $\begin{array}{l}76,719 \\
17,841 \text { USD }\end{array}$ & $\begin{array}{l}61,375 \\
14,273 \text { USD }\end{array}$ & $\begin{array}{l}92,062 \\
21,409 \text { USD }\end{array}$ & {$[8]$} \\
\hline Non-fatal stroke & $\begin{array}{l}65,928 \\
15,332 \text { USD }\end{array}$ & $\begin{array}{l}52,742 \\
12,265 \text { USD }\end{array}$ & $\begin{array}{l}79,113 \\
18,398 \text { USD }\end{array}$ & [8] \\
\hline HF (hospitalization) & $\begin{array}{l}161,249 \\
37,499 \text { USD }\end{array}$ & $\begin{array}{l}128,999 \\
29,999 \text { USD }\end{array}$ & $\begin{array}{l}193,498 \\
44,999 \text { USD }\end{array}$ & {$[8]$} \\
\hline Coronary revascularization & $\begin{array}{l}67,919 \\
15,795 \text { USD }\end{array}$ & $\begin{array}{l}54,335 \\
12,636 \text { USD }\end{array}$ & $\begin{array}{l}81,502 \\
18,953 \text { USD }\end{array}$ & {$[8]$} \\
\hline
\end{tabular}


Table 1 (continued)

\begin{tabular}{|c|c|c|c|c|}
\hline Parameter & Mean value & Low value & High value & Sources \\
\hline Retinopathy & $\begin{array}{l}20,000 \\
4651 \text { USD }\end{array}$ & $\begin{array}{l}16,000 \\
3720 \text { USD }\end{array}$ & $\begin{array}{l}24,000 \\
5581 \text { USD }\end{array}$ & [8] \\
\hline Nephropathy & $\begin{array}{l}215,695 \\
50,161 \text { USD }\end{array}$ & $\begin{array}{l}172,556 \\
40,129 \text { USD }\end{array}$ & $\begin{array}{l}258,834 \\
60,193 \text { USD }\end{array}$ & [8] \\
\hline Unstable angina pectoris (hospitalization) & $\begin{array}{l}76,719 \\
17,841 \text { USD }\end{array}$ & $\begin{array}{l}61,375 \\
14,273 \text { USD }\end{array}$ & $\begin{array}{l}92,062 \\
21,409 \text { USD }\end{array}$ & [8] \\
\hline Acute pancreatitis & $\begin{array}{l}55,883 \\
12,996 \text { USD }\end{array}$ & $\begin{array}{l}44,706 \\
10,396 \text { USD }\end{array}$ & $\begin{array}{l}67,059 \\
15,595 \text { USD }\end{array}$ & [8] \\
\hline Severe hypoglycemia & $\begin{array}{l}8059 \\
1874 \text { USD }\end{array}$ & $\begin{array}{l}6447 \\
1499 \text { USD }\end{array}$ & $\begin{array}{l}9670 \\
2248 \text { USD }\end{array}$ & [8] \\
\hline Pancreatic cancer & $\begin{array}{l}92,136 \\
21,426 \text { USD }\end{array}$ & $\begin{array}{l}73,708 \\
17,141 \text { USD }\end{array}$ & $\begin{array}{l}110,563 \\
25,712 \text { USD }\end{array}$ & [8] \\
\hline Mortality & $\begin{array}{l}750,000 \\
174,418 \text { USD }\end{array}$ & $\begin{array}{l}600,000 \\
139,534 \text { USD }\end{array}$ & $\begin{array}{l}900,000 \\
209,302 \text { USD }\end{array}$ & [8] \\
\hline
\end{tabular}

T2DM type 2 diabetes mellitus, CV cardiovascular, GLP1-RA Glucagon like peptide 1 receptor agonist, $H F$ heart failure, $M I$ myocardial infarction, SU sulphonyl urea, TZD thiazolidinediones, SGLT2i Sodium/glucose cotransporter-2 inhibitors

${ }^{\text {a }}$ Rate difference with and without liraglutide

${ }^{b}$ Rate difference with and without sitagliptin

confidence intervals. Cost parameters were varied from 10 to $20 \%$ more or less from their original value to investigate the impact they would have on the results and to confirm which parameter has the highest impact on our conclusion.

\section{Results}

The estimated target population of 120,574 T2DM adult patients associated with $\mathrm{CV}$ risk in Egypt was modeled in the budget impact analysis to compare treatment with liraglutide and sitagliptin, both in addition to the standard of care. The annual results from the perspective of private health insurers over a 3-year horizon (Figs. 2 and 3) suggest that liraglutide use results in EGP232.5 million (\$54 million) budget savings in medical (diabetic complications management) costs, while sitagliptin use results in a budget increase of EGP29 million ( $\$ 6.7$ million) in medical (diabetic complications management) costs due to an increased number of complications associated with sitagliptin. The liraglutide scenario resulted in a significant reduction in nephropathy (- $1.5 \%$ difference), mortality ( $-1.4 \%$ difference), lower event rates for HF,

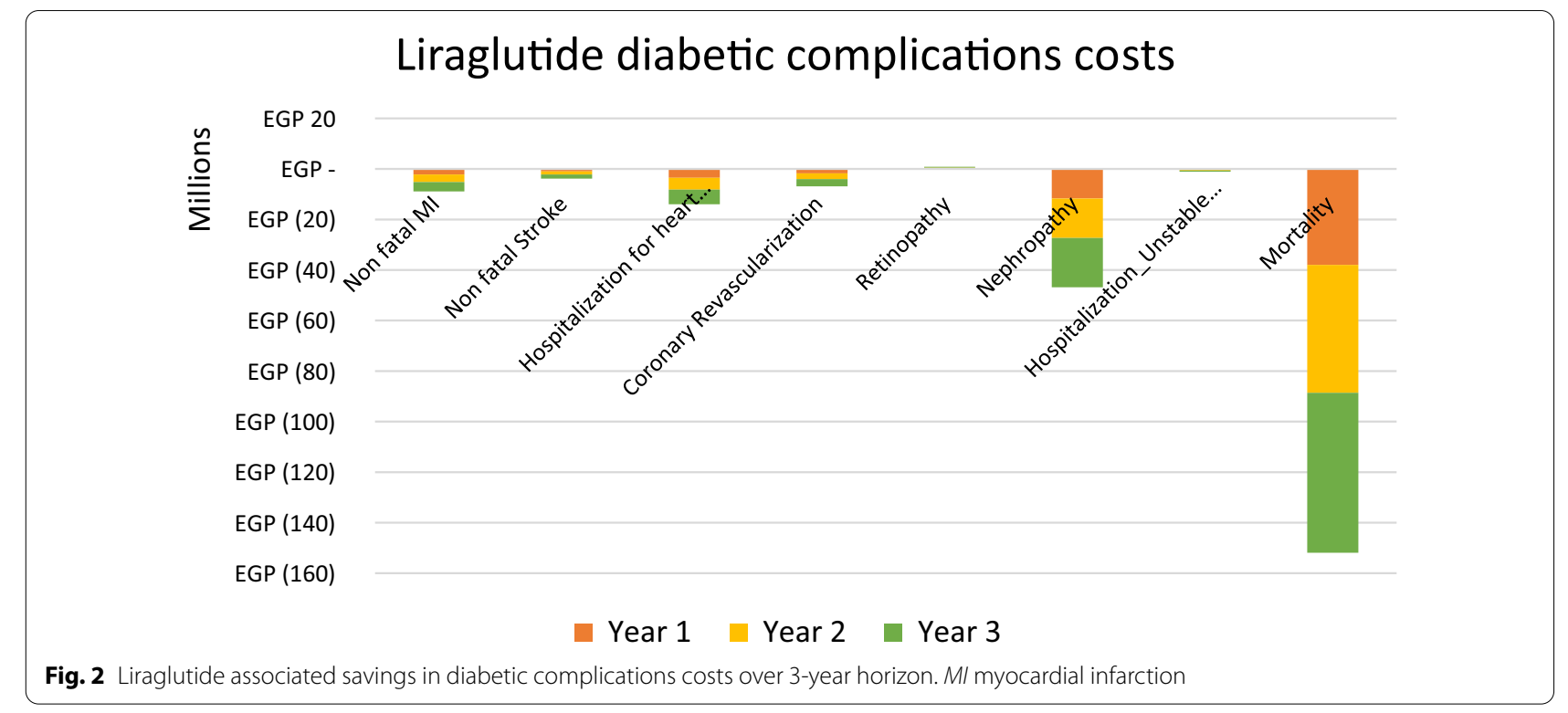




\section{Sitagliptin diabetic complications costs}

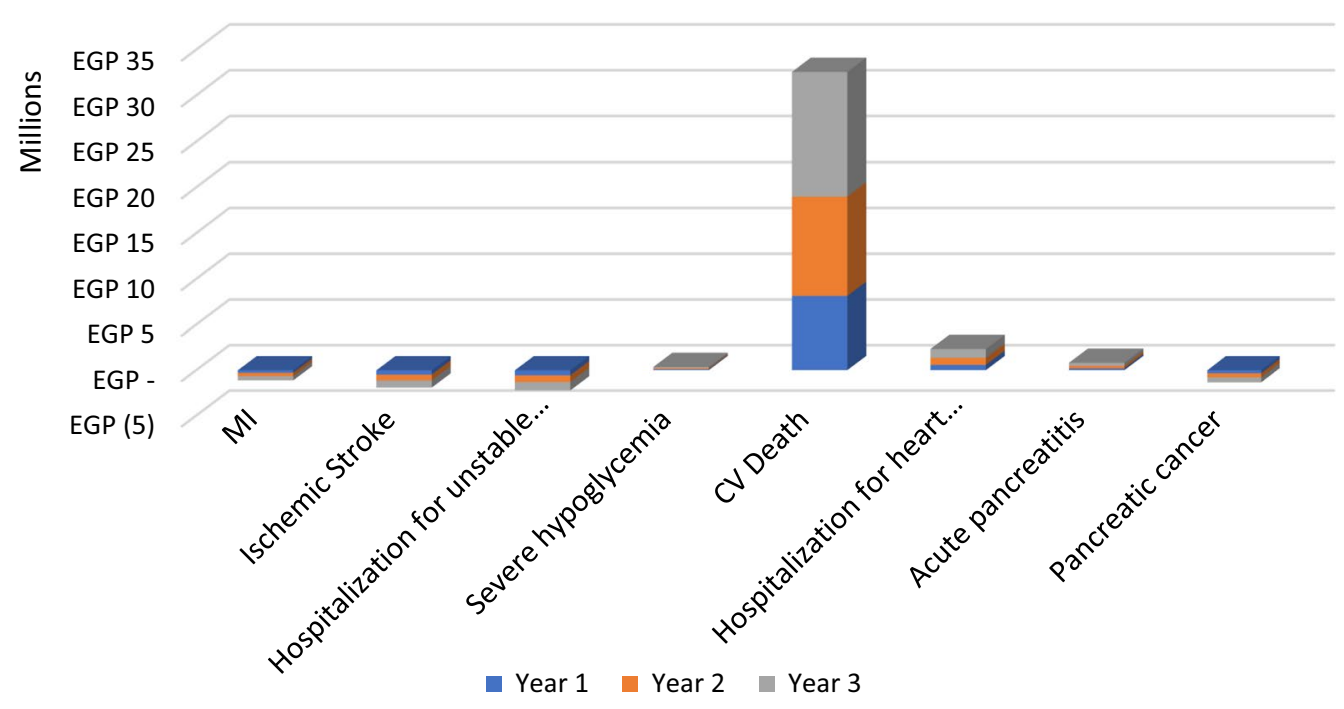

Fig. 3 Sitagliptin associated increase in diabetic complications costs over 3-year horizon. MI myocardial infarction, CV cardiovascular

coronary revascularization, MI, unstable angina pectoris, and stroke $(-0.6 \%,-0.7 \%,-0.8 \%,-0.10 \%$ and $-0.4 \%$, respectively), and a low increase in cases of retinopathy ( $0.3 \%$ difference). The sitagliptin scenario resulted in an increase in CV mortality, severe hypoglycaemia, HF hospitalization and acute pancreatitis $(0.3 \%, 0.3 \%, 0.1 \%$, and $0.1 \%$, respectively) and lower event rates for unstable angina pectoris, stroke, MI and pancreatic cancer $(-0.2 \%,-0.2 \%,-0.1 \%$ and $-0.1 \%$, respectively).

The budget impact per patient per month (PPPM) for liraglutide was EGP29 (\$6.7), EGP39 (\$9), and EGP49 $(\$ 11.3)$ in the 1st, 2nd, and 3rd years, respectively (Table 2). The budget impact PPPM for sitagliptin is EGP11 (\$2.5), EGP14 (\$3.2), and EGP18 (\$4.1) in the 1st, 2nd, and 3rd years, respectively (as shown in Table 3 ). Furthermore, adoption of liraglutide resulted in 203 fewer deaths and 550 avoided hospitalizations, while sitagliptin resulted in 43 increased deaths and 14 avoided hospitalizations. The treatment costs of liraglutide use are mostly offset by substantial savings due to fewer CVrelated events, avoided mortality and avoided hospitalizations over 3 years.

Liraglutide results in total initial savings of EGP58 million (\$13 million), EGP77 million (\$17 million), and EGP96 million (\$22 million) in the 1st, 2nd and 3rd years in medical costs, respectively, due to avoided complications and hospitalizations. The total cumulative savings over the 3 years from a private health insurance perspective are estimated at EGP232.5 million (\$54 million) (Table 2). Sitagliptin results in a total increased medical cost of EGP7 million (\$1.6 million), EGP9 million (\$2 million), and EGP12 million (\$2.7 million) in the 1st, 2nd and 3rd years, respectively, due to increased complications and hospitalizations. The total cumulative medical costs over the 3 years from a private health insurance perspective are estimated at EGP29 million (\$6.7 million) (Table 3).

\section{Sensitivity analyses}

The results of one-way deterministic sensitivity analyses (Fig. 4) suggest that the drug acquisition costs of liraglutide and its market share had the largest impact on the liraglutide model results. T2DM prevalence and the target patients diagnosed and treated with T2DM had the largest impact on the sitagliptin model results (Fig. 5).

We conducted another scenario analysis (without mortality cost) in the liraglutide budget impact model. We found that it had the same conclusion, but it resulted in budget savings of EGP80 million (\$18 million) instead of EGP232 million (\$54 million) if we included the mortality cost. 
Table 2 Base case results of liraglutide versus without liraglutide (in Egyptian Pounds)

\begin{tabular}{|c|c|c|c|c|}
\hline Parameters & Year 1 & Year 2 & Year 3 & Cumulative \\
\hline Cost of liraglutide acquisition & $\begin{array}{l}114,072,451 \\
26,528,477 \text { USD }\end{array}$ & $\begin{array}{l}152,096,602 \\
35,371,302 \text { USD }\end{array}$ & $\begin{array}{l}190,120,752 \\
44,214,128 \text { USD }\end{array}$ & $\begin{array}{l}456,289,805 \\
106,113,908 \text { USD }\end{array}$ \\
\hline Cost of standard of care by substitution ${ }^{a}$ & $\begin{array}{l}(13,000,266) \\
3,023,317 \text { USD }\end{array}$ & $\begin{array}{l}(17,333,688) \\
4,031,090 \text { USD }\end{array}$ & $\begin{array}{l}(21,667,110) \\
5,038,862 \text { USD }\end{array}$ & $\begin{array}{l}(52,001,064) \\
12,093,270 \text { USD }\end{array}$ \\
\hline Drug cost & $\begin{array}{l}101,072,185 \\
23,505,159 \text { USD }\end{array}$ & $\begin{array}{l}134,762,914 \\
31,340,212 \text { USD }\end{array}$ & $\begin{array}{l}168,453,642 \\
39,175,265 \text { USD }\end{array}$ & $\begin{array}{l}404,288,741 \\
94,020,637 \text { USD }\end{array}$ \\
\hline Non-fatal myocardial infarction & $\begin{array}{l}(2,220,074) \\
516,296 \text { USD }\end{array}$ & $\begin{array}{l}(2,960,099) \\
688,395 \text { USD }\end{array}$ & $\begin{array}{l}(3,700,124) \\
860,493 \text { USD }\end{array}$ & $\begin{array}{l}(8,880,297) \\
2,065,185 \text { USD }\end{array}$ \\
\hline Non-fatal stroke & $\begin{array}{l}(953,906) \\
221,838 \text { USD }\end{array}$ & $\begin{array}{l}(1,271,875) \\
295,784 \text { USD }\end{array}$ & $\begin{array}{l}(1,589,844) \\
369,731 \text { USD }\end{array}$ & $\begin{array}{l}(3,815,625) \\
887,354 \text { USD }\end{array}$ \\
\hline Hospitalization for heart failure & $\begin{array}{l}(3,499,637) \\
813,869 \text { USD }\end{array}$ & $\begin{array}{l}(4,666,183) \\
1,085,158 \text { USD }\end{array}$ & $\begin{array}{l}(5,832,729) \\
1,356,448 \text { USD }\end{array}$ & $\begin{array}{l}(13,998,549) \\
3,255,476 \text { USD }\end{array}$ \\
\hline Coronary revascularization & $\begin{array}{l}(1,719,736) \\
399,938 \text { USD }\end{array}$ & $\begin{array}{l}(2,292,982) \\
533,251 \text { USD }\end{array}$ & $\begin{array}{l}(2,866,227) \\
666,564 \text { USD }\end{array}$ & $\begin{array}{l}(6,878,946) \\
1,599,754 \text { USD }\end{array}$ \\
\hline Retinopathy & $\begin{array}{l}217,033 \\
50,472 \text { USD }\end{array}$ & $\begin{array}{l}289,377 \\
67,296 \text { USD }\end{array}$ & $\begin{array}{l}361,721 \\
84,121 \text { USD }\end{array}$ & $\begin{array}{l}868,131 \\
201,890 \text { USD }\end{array}$ \\
\hline Nephropathy & $\begin{array}{l}(11,703,224) \\
2,721,680 \text { USD }\end{array}$ & $\begin{array}{l}(15,604,298) \\
3,628,906 \text { USD }\end{array}$ & $\begin{array}{l}(19,505,373) \\
4,536,133 \text { USD }\end{array}$ & $\begin{array}{l}(46,812,895) \\
10,886,719\end{array}$ \\
\hline Hospitalization_unstable angina pectoris & $\begin{array}{l}(277,509) \\
64,536 \text { USD }\end{array}$ & $\begin{array}{l}(370,012) \\
86,049 \text { USD }\end{array}$ & $\begin{array}{l}(462,515) \\
107,561 \text { USD }\end{array}$ & $\begin{array}{l}(1,110,037) \\
258,148 \text { USD }\end{array}$ \\
\hline Mortality & $\begin{array}{l}(37,980,744) \\
8,832,731 \text { USD }\end{array}$ & $\begin{array}{l}(50,640,992) \\
11,776,974 \text { USD }\end{array}$ & $\begin{array}{l}(63,301,240) \\
14,721,218 \text { USD }\end{array}$ & $\begin{array}{l}(151,922,975) \\
35,330,924 \text { USD }\end{array}$ \\
\hline Medical costs & $\begin{array}{l}(58,137,798) \\
13,520,418 \text { USD }\end{array}$ & $\begin{array}{l}(77,517,064) \\
18,027,224 \text { USD }\end{array}$ & $\begin{array}{l}(96,896,330) \\
22,534,030 \text { USD }\end{array}$ & $\begin{array}{l}(232,551,192) \\
54,081,672 \text { USD }\end{array}$ \\
\hline Total costs PPPM & $\begin{array}{l}29 \\
6.74 \text { USD }\end{array}$ & $\begin{array}{l}39 \\
9.06 \text { USD }\end{array}$ & $\begin{array}{l}49 \\
11.39 \text { USD }\end{array}$ & $\begin{array}{l}39 \\
9.06 \text { USD }\end{array}$ \\
\hline
\end{tabular}

PPPM per patient per month

${ }^{a}$ We substituted the market share of the glucose lowering drugs with liraglutide

\section{Discussion}

Liraglutide was approved by the European Medicines Agency in 2009 and United States Food and Drug Administration in 2010, and is sold in more than 80 countries to treat T2DM patients [10,11]. Our results demonstrate that the upfront costs of liraglutide $1.8 \mathrm{mg}$ are mostly offset by budget savings due to fewer $\mathrm{CV}$-related events and premature mortality avoided (550 avoided hospitalizations and 203 avoided deaths, respectively).

Prior analyses on liraglutide use among T2DM patients also reported cost savings. In a budget impact study conducted from the Algerian healthcare payer's perspective, liraglutide $1.2 \mathrm{mg}$ resulted in cost savings compared to insulin glargine among patients insufficiently controlled on oral antidiabetics [12]. Authors reported that more patients reached the target $\mathrm{HbA1c}$ level without the need for intensified treatment regimens, unlike basal insulin, which in $79 \%$ of cases requires intensification to a basal-bolus regime or twice daily premix therapy, both of which have higher direct costs [12]. A study in Italy used real-world market consumption data and found that adding liraglutide versus standard of care increased the cost per patient between $€ 8.04$ and $€ 25.00$. This study did not consider the cost of complications and thus did not offset the elevated drug acquisition cost with the cost savings from the reduced rates of complications associated with liraglutide [13]. Another study assessed the budget impact and the cost-effectiveness of liraglutide versus the standard of care from the US healthcare payer perspective. Over the lifetime of T2DM patients included in the analysis and with confirmed cardiovascular disease or high cardiovascular risk, liraglutide use was budget neutral and cost-effective [14].

In the United Kingdom, a study on the cost-effectiveness of liraglutide (1.2 and $1.8 \mathrm{mg}$, daily) versus dapagliflozin (10 mg, daily) among T2DM patients concluded that both doses of liraglutide may be cost-effective treatments as a second or third addition to standard of care for patients who are not eligible for SGLT-2i therapy 
Table 3 Base case results of sitagliptin versus without sitagliptin (in Egyptian Pounds)

\begin{tabular}{|c|c|c|c|c|}
\hline Parameter & Year 1 & Year 2 & Year 3 & Cumulative \\
\hline Cost of sitagliptin acquisition & $\begin{array}{l}14,324,166 \\
3,331,201 \text { USD }\end{array}$ & $\begin{array}{l}19,098,888 \\
4,441,601 \text { USD }\end{array}$ & $\begin{array}{l}23,873,610 \\
5,552,002 \text { USD }\end{array}$ & $\begin{array}{l}57,296,665 \\
13,324,805 \text { USD }\end{array}$ \\
\hline Cost of standard of care by substitution ${ }^{a}$ & $\begin{array}{l}(5,823,714) \\
1,354,352 \text { USD }\end{array}$ & $\begin{array}{l}(7,764,952) \\
1,805,802 \text { USD }\end{array}$ & $\begin{array}{l}(9,706,190) \\
2,257,253 \text { USD }\end{array}$ & $\begin{array}{l}(23,294,856) \\
5,417,408 \text { USD }\end{array}$ \\
\hline Drug cost & $\begin{array}{l}8,500,452 \\
1,976,849 \text { USD }\end{array}$ & $\begin{array}{l}11,333,936 \\
2,635,799 \text { USD }\end{array}$ & $\begin{array}{l}14,167,420 \\
3,294,748 \text { USD }\end{array}$ & $\begin{array}{l}34,001,809 \\
7,907,397 \text { USD }\end{array}$ \\
\hline Ml & $\begin{array}{l}(277,509) \\
64,536 \text { USD }\end{array}$ & $\begin{array}{l}(370,012) \\
86,049 \text { USD }\end{array}$ & $\begin{array}{l}(462,515) \\
107,561 \text { USD }\end{array}$ & $\begin{array}{l}(1,110,037) \\
258,148 \text { USD }\end{array}$ \\
\hline Ischemic stroke & $\begin{array}{l}(476,953) \\
110,919 \text { USD }\end{array}$ & $\begin{array}{l}(635,938) \\
151,413 \text { USD }\end{array}$ & $\begin{array}{l}(794,922) \\
184,865 \\
\text { USD }\end{array}$ & $\begin{array}{l}(1,907,813) \\
443,677 \text { USD }\end{array}$ \\
\hline Hospitalization for unstable angina & $\begin{array}{l}(555,019) \\
129,074 \text { USD }\end{array}$ & $\begin{array}{l}(740,025) \\
172,098 \text { USD }\end{array}$ & $\begin{array}{l}(925,031) \\
215,123 \text { USD }\end{array}$ & $\begin{array}{l}(2,220,074) \\
516,296 \text { USD }\end{array}$ \\
\hline Severe hypoglycemia & $\begin{array}{l}87,453 \\
20,337 \text { USD }\end{array}$ & $\begin{array}{l}116,605 \\
27,117 \text { USD }\end{array}$ & $\begin{array}{l}145,756 \\
33,896 \text { USD }\end{array}$ & $\begin{array}{l}349,814 \\
81,352 \text { USD }\end{array}$ \\
\hline CV death & $\begin{array}{l}8,138,731 \\
1,892,728 \text { USD }\end{array}$ & $\begin{array}{l}10,851,641 \\
2,523,637 \text { USD }\end{array}$ & $\begin{array}{l}13,564,551 \\
3,154,546 \text { USD }\end{array}$ & $\begin{array}{l}32,554,923 \\
7,570,912 \text { USD }\end{array}$ \\
\hline Hospitalization for heart failure or CV death & $\begin{array}{l}583,273 \\
135,644 \text { USD }\end{array}$ & $\begin{array}{l}777,697 \\
180,859 \text { USD }\end{array}$ & $\begin{array}{l}972,121 \\
226,074 \text { USD }\end{array}$ & $\begin{array}{l}2,333,091 \\
542,579 \text { USD }\end{array}$ \\
\hline Acute pancreatitis & $\begin{array}{l}202,139 \\
47,009 \text { USD }\end{array}$ & $\begin{array}{l}269,519 \\
62,678 \text { USD }\end{array}$ & $\begin{array}{l}336,898 \\
78,348 \text { USD }\end{array}$ & $\begin{array}{l}808,556 \\
188,036 \text { USD }\end{array}$ \\
\hline Pancreatic cancer & $\begin{array}{l}(333,276) \\
77,506 \text { USD }\end{array}$ & $\begin{array}{l}(444,367) \\
103,341 \text { USD }\end{array}$ & $\begin{array}{l}(555,459) \\
129,176 \text { USD }\end{array}$ & $\begin{array}{l}(1,333,102) \\
310,023 \text { USD }\end{array}$ \\
\hline Medical costs & $\begin{array}{l}7,368,839 \\
1,713,683 \text { USD }\end{array}$ & $\begin{array}{l}9,825,119 \\
2,284,911 \text { USD }\end{array}$ & $\begin{array}{l}12,281,399 \\
2,856,139 \text { USD }\end{array}$ & $\begin{array}{l}29,475,358 \\
6,854,734 \text { USD }\end{array}$ \\
\hline Total costs PPPM & $\begin{array}{l}11 \\
2.55 \text { USD }\end{array}$ & $\begin{array}{l}14 \\
3.25 \text { USD }\end{array}$ & $\begin{array}{l}18 \\
4.18 \text { USD }\end{array}$ & $\begin{array}{l}14 \\
3.25 \text { USD }\end{array}$ \\
\hline
\end{tabular}

PPPM per patient per month

${ }^{a}$ We substituted the market share of the glucose lowering drugs with sitagliptin

[15]. In Italy, a cost-effectiveness study of liraglutide $1.8 \mathrm{mg}$ versus lixisenatide $20 \mu \mathrm{g}$ (both are GLP-1 receptor agonists) for treating T2DM patients unable to reach acceptable blood glucose levels on metformin concluded that liraglutide $1.8 \mathrm{mg}$ is likely to be cost-effective versus lixisenatide $20 \mu \mathrm{g}$ in Italian settings [16]. In France, a study comparing liraglutide, sitagliptin and glimepiride as add-ons for patients not reaching the target $\mathrm{HbA1c}$ level found that while all fell below the willingness-topay threshold, liraglutide was the most cost-effective [17]. The findings of this study were of great significance, as they included CV death and all-cause death outcomes, which is the case with our model. Last, in Spain, a study comparing $1.8 \mathrm{mg}$ liraglutide and sitagliptin as intensifications for patients on metformin above the target HbA1c levels concluded that $1.8 \mathrm{mg}$ liraglutide is costeffective compared to sitagliptin in Spanish settings [18].

When considering the ISPOR Special Task Force in defining the elements of value in health care that were not captured in our model due to lack of local data [19], we found that the addition of liraglutide not only provided high-quality adjusted life years (QALYs), life years gained (LYsG) and productivity values as innovative treatment of Egyptian T2DM patients when compared to standard of care but also provided the following novel health values: value of hope, real option value, adding more value in severity of disease and as a scientific spillover.

Our study was modeled on the best available evidence from the LEADER and TECOS trials. The budget impact model simulated a patient cohort covered by private health insurance in Egypt and integrated local clinical practice and epidemiological inputs validated by an expert panel. We also included various sensitivity analyses to ensure the robustness of the model and to detect any uncertainties. Our study was limited by the use of an international clinical trial with results that may not be specific to Egypt. Variations exist in treatment patterns between countries [3]. Second limitation, these results 


\section{Tornado Diagram}

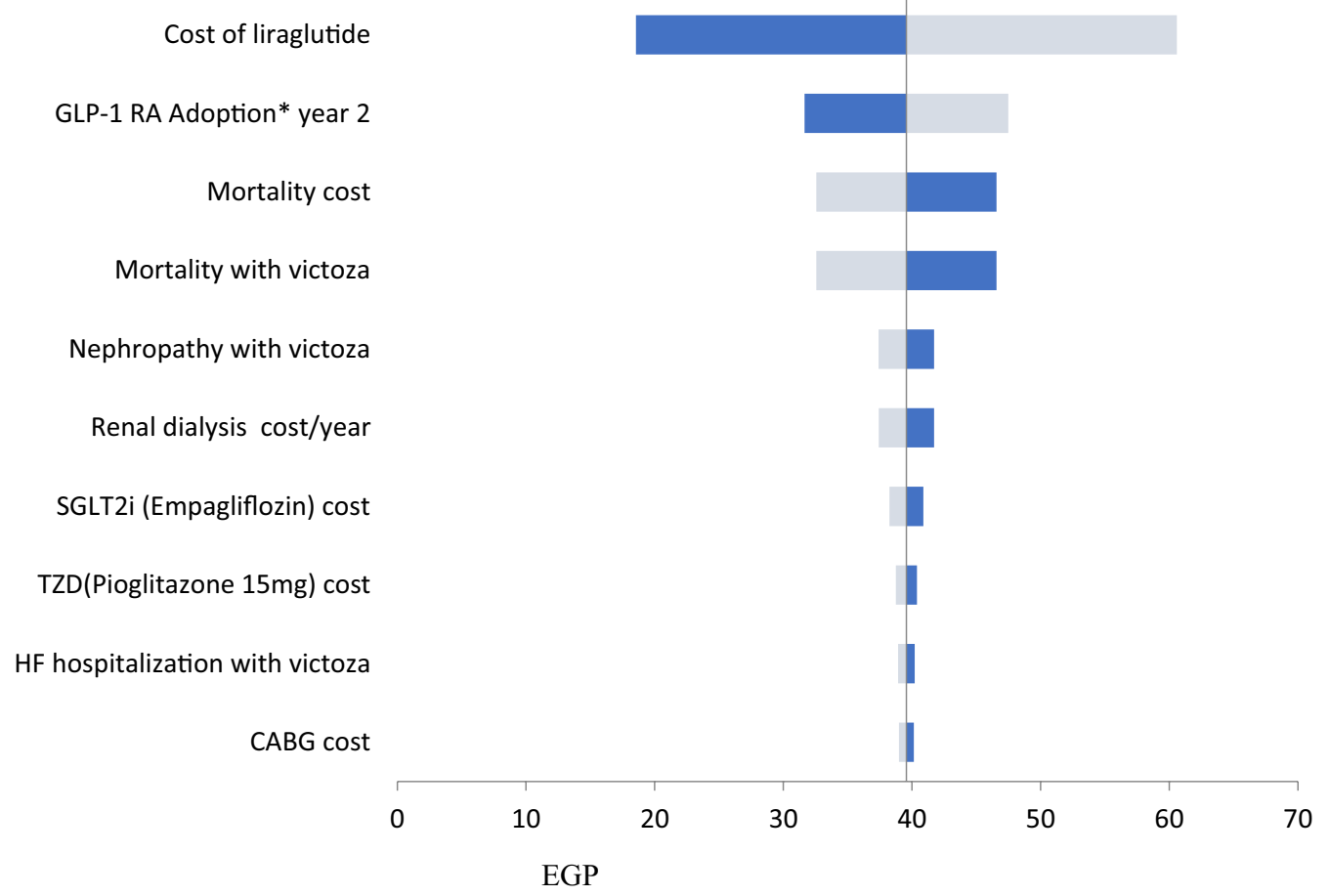

Fig. 4 One-way sensitivity analysis results for liraglutide. GLP1-RA Glucagon like peptide 1 receptor agonist, SGLT2i Sodium/glucose cotransporter-2 inhibitors, TZD thiazolidinediones, HF heart failure, CABG Coronary artery bypass graft. The light grey bar corresponds with the upper range, and the dark blue bar with the lower range of an input

could not be generalized to the Egyptian public health care system as the unit costs are varied between the public and the private health care system. Third limitation, we did not conduct probabilistic sensitivity analyses because they are not mandatory according to Egyptian pharmacoeconomic guidelines [20]. Furthermore, ISPOR Task Force on Good Research Practices-Budget Impact Analysis mentioned in their report that sensitivity analysis should be in the form of alternative scenarios chosen from the perspective of the decision-maker and their usefulness depends on the amount and quality of available data and the needs of the decision-maker [9]. Fourth limitation, we did not conduct indirect treatment comparisons i.e. network meta-analysis for a matter of simplification and better understanding by policy makers and private health insurers. Our results would be strengthened with clinical parameters specific to Egypt. However, such variations may be negligible because the standard of care of Egypt does not differ compared to countries included in the clinical trials, and Egyptian clinical practice is based on international treatment guidelines (American Diabetes Association Guidelines) [21]. Another strength of our study was the inclusion of mortality costs, as our analysis was conducted from a private health insurance perspective, and around $85 \%$ of the private insurance companies pay life insurance to the families of dead patients.

\section{Conclusion}

The adoption of liraglutide resulted in 203 deaths avoided and 550 hospitalizations avoided. Adding liraglutide resulted in a modest budget impact of EGP 29 (\$6.7)-EGP 49 (\$11.3) PPPM, suggesting that the upfront drug costs were offset by budget savings due to fewer CV-related complications and deaths avoided. Sitagliptin resulted in a budget impact of EGP 11(\$2.5)-EGP 18 (\$4.1) PPPM but was associated with 43 deaths and 14 hospitalizations avoided compared to the standard of care in Egypt from the private health insurance perspective. 


\section{Tornado Diagram}

\section{T2DM prevalence}

Proportion of people with T2DM diagnosed \& treated

Percentage of patients with CV morbidity

Percentage of patients covered by PHI

Sitagliptin 100 cost

Mortality cost

CV Death_DPP4

DPP4 Adoption* year 2

TZD(Pioglitazone 15mg) cost

SU (Gliclazide $60 \mathrm{mg}$ ) cost

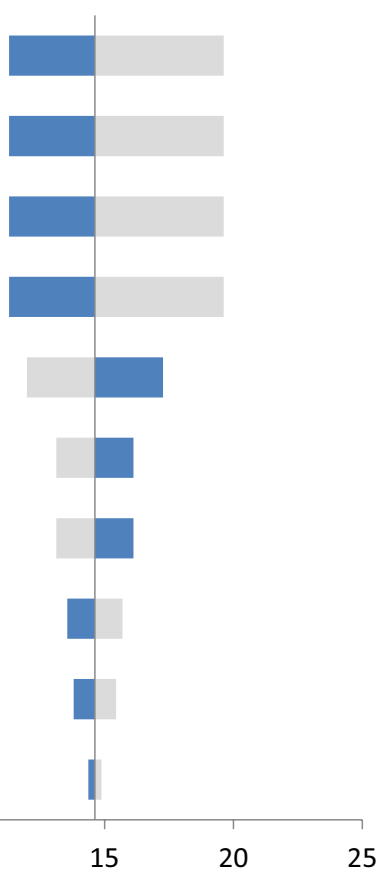

EGP

Fig. 5 One-way sensitivity analysis results for sitagliptin. T2DM type 2 diabetes mellitus, $C V$ cardiovascular, $P H I$ private health insurance, DPP4 dipeptidyl peptidase 4, TZD thiazolidinediones, SU sulphonyl urea. The light grey bar corresponds with the upper range, and the dark blue bar with the lower range of an input

Acknowledgements

No acknowledgement.

\section{Authors' contributions}

$A A, E Z, N N, H N$, and NR analyzed and interpreted the collected data. GE made a major contribution in writing the manuscript and building the model. JC helped in writing the manuscript. AA collected needed data about treatments cost. All authors read and approved the final manuscript.

\section{Funding}

This study was funded by NovoNordisk Egypt.

\section{Availability of data and materials}

This article is a budget impact analysis, and thus there are no underlying data used for this research apart from the data extracted from the articles included in this review. Cost data used to inform the budget impact analysis are available from the corresponding author upon reasonable request.

\section{Declarations}

Ethics approval and consent to participate

Not applicable.

\section{Consent for publication}

Not applicable.

\section{Competing interests}

Elsisi G, Abgad A, Zakaria E, Nasif N, Naiem H, Raafat N, Carapinha J. have no conflicts of interest directly relevant to the content of this article. Afify $\mathrm{A}$ is employed in Novonordisk Egypt.

\begin{abstract}
Author details
${ }^{1}$ HTA Office, LLC, Cairo, Egypt. ${ }^{2}$ Cairo University \& American University in Cairo, 51 Helmy Hassan Aly St., Mostafa Elnahas, Nasr City, Cairo, Egypt. ${ }^{3}$ Market Access and Public Affairs, Novonordisk, Cairo, Egypt. ${ }^{4}$ Faculty of Medicine, Alex University, Alexandria, Egypt. ${ }^{5}$ Faculty of Medicine, Cairo University, Giza, Egypt. ${ }^{6}$ Faculty of Medicine, Ain Shams University, Cairo, Egypt. ${ }^{7}$ Diabetes and Neuropathy Clinic, Cairo, Egypt. ${ }^{8}$ Faculty of Medicine, Al-Azhar University, Cairo, Egypt. ${ }^{9}$ School of Pharmacy, North-Eastern University, Boston, USA.
\end{abstract}

Received: 3 August 2021 Accepted: 27 December 2021

Published online: 15 January 2022

\section{References}

1. Khunti S, Khunti K, Seidu S. Therapeutic inertia in type 2 diabetes: prevalence, causes, consequences and methods to overcome inertia. Ther Adv Endocrinol Metabol. 2019;10:2042018819844694.

2. Hegazi R, El-Gamal M, Abdel-Hady N, Hamdy O. Epidemiology of and risk factors for type 2 diabetes in Egypt. Ann Glob Health. 2015;81 (6):814-20.

3. Marso SP, Daniels GH, Brown-Frandsen K, Kristensen P, Mann JF, Nauck $\mathrm{MA}$, et al. Liraglutide and cardiovascular outcomes in type 2 diabetes. $\mathrm{N}$ Engl J Med. 2016;375(4):311-22.

4. Green JB, Bethel MA, Armstrong PW, Buse JB, Engel SS, Garg J, et al. Effect of sitagliptin on cardiovascular outcomes in type 2 diabetes. N Engl J Med. 2015;373:232-42.

5. Egypt-The World Factbook. CIA Factbook. 2020. https://www.cia.gov/ the-world-factbook/countries/egypt.

6. CDC. National diabetes statistical report. 2020. https://www.cdc.gov/ diabetes/pdfs/data/statistics/national-diabetes-statistics-report.pdf. 
7. AXA research (unpublished work). 2019.

8. Private sector hospitals (Alaraby hospital, Cleopatra hospital, Nasser Institute and Elkasr Eleiny hospital). 2020.

9. Mauskopf JA, Sullivan SD, Annemans L, Caro J, Mullins CD, Nuijten M, Orlewska E, Watkins J, Trueman P. Principles of good practice for budget impact analysis: report of the ISPOR Task Force on good research practices-budget impact analysis. Value Health. 2007;10(5):336-47.

10. EMA. Victoza ${ }^{\circledR}$ EU summary of product characteristics. November 2015. http://www.ema.europa.eu/docs/en_GB/document_library/EPAR_Product_Information/human/001026/WC500050017.pdf.

11. United States Food and Drug Administration. Drug approval package. https://www.accessdata.fda.gov/drugsatfda_docs/nda/2010/022341s000 TOC.cfm.

12. Sellam Y. Budget impact savings of liraglutide $1,2 \mathrm{mg}$ versus insulin in algerian $\mathrm{t} 2 \mathrm{~d}$ patients insufficiently controlled with oral medications. Value Health. 2019;22:S146.

13. Capri S, Barbieri M. Estimating the budget impact of innovative pharmacological treatments for patients with type 2 diabetes mellitus in Italy: the case of liraglutide (GLP-1). Epidemiol Biostat Public Health. 2015. https:// doi.org/10.2427/11082.

14. Shah D, Risebrough NA, Perdrizet J, lyer NN, Gamble C, Dang-Tan T. Costeffectiveness and budget impact of liraglutide in type 2 diabetes patients with elevated cardiovascular risk: a US-managed care perspective. ClinicoEcon Outcomes Res CEOR. 2018;10:791.

15. Vega-Hernandez G, Wojcik R, Schlueter M. Cost-effectiveness of liraglutide versus dapagliflozin for the treatment of patients with type 2 diabetes mellitus in the UK. Diabetes Ther. 2017;8(3):513-30.

16. Hunt B, Kragh N, McConnachie CC, Valentine WJ, Rossi MC, Montagnoli R. Long-term cost-effectiveness of two GLP-1 receptor agonists for the treatment of type 2 diabetes mellitus in the Italian setting: liraglutide versus lixisenatide. Clin Ther. 2017:39(7):1347-59.

17. Roussel R, Martinez L, Vandebrouck T, Douik H, Emiel P, Guery M, Hunt $B$, Valentine WJ. Evaluation of the long-term cost-effectiveness of liraglutide therapy for patients with type 2 diabetes in France. J Med Econ. 2016;19(2):131-44.

18. Pérez A, Raya PM, De Arellano AR, Briones T, Hunt B, Valentine WJ. Costeffectiveness analysis of incretin therapy for type 2 diabetes in Spain: 1.8 mg liraglutide versus sitagliptin. Diabetes Ther. 2015;6(1):61-74.

19. Lakdawalla DN, Doshi JA, Garrison LP Jr, Phelps CE, Basu A, Danzon PM. Defining elements of value in health care-a health economics approach: an ISPOR Special Task Force report. Value Health. 2018;21(2):131-9.

20. Elsisi GH, Kaló Z, Eldessouki R, et al. Recommendations for reporting pharmacoeconomic evaluations in Egypt. Value Health Reg Issues. 2013;2:319-27.

21. $\mathrm{MOH}$. Egyptian clinical practice recommendations for management of diabetes mellitus. Med J Cairo Univ. 2015.

\section{Publisher's Note}

Springer Nature remains neutral with regard to jurisdictional claims in published maps and institutional affiliations.

Ready to submit your research? Choose BMC and benefit from:

- fast, convenient online submission

- thorough peer review by experienced researchers in your field

- rapid publication on acceptance

- support for research data, including large and complex data types

- gold Open Access which fosters wider collaboration and increased citations

- maximum visibility for your research: over $100 \mathrm{M}$ website views per year

At BMC, research is always in progress.

Learn more biomedcentral.com/submissions 